\title{
Listen to your curiosity about how to improve patient care through research
}

\author{
Steven David Williams (i) 1,2
}

Tommy Eriksson, deputy editor of this journal, has urged our readers to consider undertaking research and publishing it in the European Journal of Hospital Pharmacy (EJHP) to highlight innovations and developments in science and promoting safe effective and cost-effective pharmaceutical care. ${ }^{1}$

So why don't you get involved in research? You're reading this journal so you must be interested in improving patient care?

My fellow associate editor Paul le Brun makes a persuasive argument about the need for pharmacists to retain the knowledge and skills in the preparation and analysis of medicines to perform product-focussed research. ${ }^{2}$ He rightly points out that there is no patient care without product care. However there is also no patient care without blood tests or diagnostic imaging, the majority of which is provided by automated technology and technical staff, with only the need for a small number of 'field experts' to then oversee medical advances. So, I think that product-focussed research is still for a niche group, whilst the vast majority of pharmacists are focussed on patient care.

As Albert Einstein, perhaps Europe's best scientist said 'the important thing is not to stop questioning. Curiosity has its own reason for existing'. Pharmacists are curious by nature but traditionally are not research focussed. Whatever you are curious about, for example:why do

\footnotetext{
1Pharmacy, Westbourne Medical Centre, Bournemouth, UK

${ }^{2}$ Manchester Pharmacy School, University of

Manchester, Manchester, UK
}

Correspondence to Steven David Williams, Pharmacy, Westbourne Medical Centre, Bournemouth BH4 9HJ, UK; stevethechemist@gmail.com a large proportion of my cystic fibrosis patients not take their mediation when they know they have a life limiting illness? Why does our pharmacy department make dispensing errors despite having a dispensing robot? What do patients think of our new outpatients complex Medicines Reconciliation service?

I first became interested in research when I became increasingly curious about why pharmacists did not appear to report medication incidents very often. I convinced myself that if they had personal digital assistants PDAs (before we had smart phones) they would report more. I started speaking to a pharmacist researcher at my local university and with support from my chief pharmacist agreed to do a part time Masters looking into the subject. After just one conversation with my academic supervisor, it was clear that my hypothesis was completely flawed. Instead, my research question became 'what are the attitudes of hospital pharmacists to reporting medication incidents?' After a systematic literature search, some focus groups and a psychology-based questionnaire I had my answer. Reporting simplicity, such as using PDAs, might be important but only after pharmacists have confidence that reporting will lead to positive change (and not get anyone into trouble) and then have clarity about what types of incident they are expected to report, as the number of medication incidents is so prevalent. ${ }^{34}$

Research is a journey, but you are all patient-focussed scientists and there are plenty of people that you can turn to for advice, to help you reach your destination. Granted, it is not like asking Google how to get from a to b? The write up of my Masters, while working, nearly killed me but 'everything is hard before it gets easy' and the feeling when you finally arrive is as good as helping a patient with intractable migraines find the right treatment regimen.

Your situation may be that full-blown research is currently not possible in your current role, but before I got interested in research, I cut my teeth on service development and clinical audit. Done well with good methodology, after reviewing the current literature, the journal is also interested in publishing these so that others could replicate it for the benefit of their patients or service.

So, listen to your curiosity about how to improve patient care, seek some advice locally and then submit your work to the EJHP?

Funding The authors have not declared a specific grant for this research from any funding agency in the public, commercial or not-for-profit sectors.

Competing interests None declared.

Provenance and peer review Not commissioned; internally peer reviewed.

(c) European Association of Hospital Pharmacists 2019. No commercial re-use. See rights and permissions. Published by BMJ.

$$
\text { D Check for updates }
$$

To cite Williams SD. Eur J Hosp Pharm 2019;26:299. Published Online First 11 October 2019

Eur J Hosp Pharm 2019;26:299.

doi:10.1136/ejhpharm-2019-002085

ORCID iD

Steven David Williams http://orcid.org/0000-00019080-5897

\section{REFERENCES}

1 Eriksson T. What is a hospital pharmacist, our competencies? Eur J Hosp Pharm 2019;26:185-6.

2 Le Brun PPH. Preparation has a future! Eur J Hosp Pharm 2019;26:300.

3 Williams SD, Phipps DL, Ashcroft DM. Understanding the attitudes of hospital pharmacists to reporting medication incidents: a qualitative study. Res Social Adm Pharm 2013;9:80-9.

4 Williams SD, Phipps DL, Ashcroft D. Examining the attitudes of hospital pharmacists to reporting medication safety incidents using the theory of planned behaviour. Int I Qual Health Care 2015;27:297-304 